\title{
THE INFLUENCE OF PRENATAL CLASS PARTICIPATION TOWARDS MATERNAL BEHAVIOR DURING POSTNATAL IN KEDIRI DISTRICT
}

\author{
Dian Kumalasari ${ }^{1)}$, Candra Dewinataningtyas ${ }^{2)}$, Elin Soyanita ${ }^{3)}$ \\ Email: diankyumalasari.88@gmail.com \\ ${ }^{1,2,3}$ Prodi D3 Kebidanan Institut Ilmu Kesehatan Bhakti Wiyata \\ Jalan KH. Wahid Hasyim 65 Kediri
}

\section{Article Information}

Received:

September 07, 2019

Revised:

December 27, 2019

Accepted:

January 19, 2020

Available online:

January 23, 2020

\begin{abstract}
Optimal puerperal care can reduce complications that occur during the puerperium. Information about childbirth care can be obtained through participation in prenatal classes. Through the prenatal class, mothers expected to gain knowledge to change the behavior of mothers regarding postnatal care. The purpose of this study was to determine the influence of participation in prenatal class on postpartum behavior. This study was a quantitative study with a descriptive-analytic study through the cross-sectional approach. The sampling technique used purposive sampling. The sample used was 80 postpartum mothers. The data analysis technique used a statistical test using Chi-square tests. The results of the study showed that mothers who attended a prenatal class by $59(73.8 \%)$ and postpartum behavior showed an excellent category of 71 $(88.8 \%)$. There were significant relationships between class participation in a prenatal class and maternal behavior during postnatal, as indicated by the value of $\mathrm{p}$-value $=0.001$. The activeness of mothers participating in a prenatal class can improve maternal behavior in postpartum care to be better and optimal.
\end{abstract}

Keywords: prenatal classes, maternal behavior, postnatal care

\section{Introduction}

Health problems that occur in the current era of globalization were the low health status of mothers and children who were still lacking — this figure marked by the high maternal mortality rate and infant mortality rate. Based on WHO (2015), maternal rate around the world estimated 216 / 100,000 live births; this condition was very far from the SDG target, which agreed on maternal mortality rates of $70 / 100,000$ live births in 2030. Maternal mortality rates survey results in Indonesia showed a change to 305 / 100,000 live births ${ }^{[1]}$. In 2016, maternal mortality rates of East Java Province reached 91.00 / 100,000 live births (East Java Provincial Health Profile, 2016), while in Kediri district reached 17 / 100,000 live births. ${ }^{[2]}$
Based on the data above, the causes of maternal death due to heart attack (35.3\%), other causes (29.4\%), preeclampsia (17.6\%), and hemorrhage $(17.6 \%)$. The fatal period is in the puerperium, which was $44 \%$, especially on days $8-14^{[2]}$. Maternal mortality that occurs during the puerperium can be caused by suboptimal puerperal care.

The government continues to strive to overcome these problems, one of which was by increasing the knowledge and active role of mothers, families, and communities through the prenatal class program. Prenatal class is an activity of discussing maternal and child health or known as KIA handbook material in the form of face-to-face groups followed by discussion and exchange of experiences between 
pregnant women and health workers. ${ }^{[3]}$ Prenatal classes aim to improve the attitudes, knowledge, and skills of mothers in postnatal care.

Increased knowledge and skills of mothers seen from behavior in their daily lives. Changes in postnatal mothers' behavior are influenced by knowledge and attitudes. A fully realized attitude will lead to a response in the form of actions or behavior to carry out postpartum care. ${ }^{[4]}$

Widyaningrum (2014) stated that the prenatal class influenced postnatal maternal satisfaction in conducting postnatal care. ${ }^{[5]}$ Joharmi and Brahmana (2017) also stated that one of the factors affecting postnatal care was knowledge about the puerperium. It was due to the lack of counseling about postnatal care. ${ }^{[6]}$

The authors consider it necessary to conduct this study to analyze postnatal maternal behavior in daily care. In general, this study aims to analyze the effect of prenatal class participation on maternal behavior in the puerperium. The specific objectives of this research include analyzing the effect of prenatal class participation on maternal behavior during postnatal.

\section{Method}

This study was a quantitative study with a cross-sectional design. The sample used purposive sampling of about 80 postnatal mothers - this study conducted in three Community Health Center, namely Blabak, Gurah, and Wonorejo. Data collected from May-July 2019. The independent variable was the prenatal class participation, while the dependent variable was maternal behavior during postnatal.

The instrument used a questionnaire. After the data was collected, the data processing was done by editing, coding, scoring, data entry, and tabulating data. Data analysis was performed with univariate analysis to get a picture of the frequency distribution of respondents, and bivariate analysis was carried out to see the relationship between independent and dependent factors using the Chi-Square test.

\section{Results and discussion}

a. Univariate Analysis

From the results of the study obtained the characteristics of respondents by age are presented in table 1 below.

Table 1 Frequency Distribution of Age

\begin{tabular}{ccc}
\hline $\begin{array}{c}\text { Age } \\
\text { (years old) }\end{array}$ & F & $\%$ \\
\hline 20 & 3 & 3.75 \\
$21-35$ & 65 & 81.25 \\
$<35$ & 12 & 15 \\
Total & 80 & 100 \\
\hline
\end{tabular}

Based on the information in Table 1 above, it shows that the youngest respondent was 18 years old, and the oldest respondent was 42 . years old. The average age of respondents in this study was 29 years.

From the results of the study, it was found that the age range of most respondents was 20-35 years, in this age supports one's ability to receive information. The more mature the respondent's age, it is expected that the respondent's ability to receive information when attending a prenatal class is better. This explanation is in line with Pertiwi's research (2017), which stated that a mature age would experience proper mental development so that the knowledge obtained from information will also be better. ${ }^{[7]}$ Rahayuningsih (2015) explains that maternal age was significantly related to the mother's knowledge about care puerperal. The more mature a person was, the easier it was to receive information, to gain knowledge about good postnatal care.

Characteristics of respondents based on their level of education are presented in Table 2 below. 
Table 2 Frequency Distribution of Education Level

\begin{tabular}{ccc}
\hline Education Level & f & \% \\
\hline Junior High School & 19 & 23.8 \\
High School/ & 44 & 55 \\
Vocational & 3 & 3.8 \\
Diploma & 14 & 17.5 \\
Bachelor & 80 & 100 \\
Total & &
\end{tabular}

Based on the information in Table 2 above, it showed that 44 respondents in this study had a high school / vocational education level, while respondents who had a junior high school were 19 respondents. Respondents with Diploma were three respondents, and those with bachelor were 14 respondents.

The education level of the respondents is mostly high school graduates. The higher the education of mothers expected to have the ability to receive information would be higher.

Ali (2009) stated that education must be accompanied by knowledge, attitudes, and skills so that it can shape the expected behavior. Knowledge can be obtained when attending prenatal classes. Education is one of the factors expected to improve maternal behavior in postnatal care.

According to Hardjito et al. (2018) education influence the learning process, the higher a person's education was, the easier he will receive information, with higher education, a person will tend to get information, both from other people and the mass media. ${ }^{[8]}$

Table 3 Frequency Distribution of

\begin{tabular}{lcc}
\multicolumn{1}{c}{ Occupation } & & \\
\hline Occupation & f & \% \\
\hline Midwives & 1 & 1.3 \\
Teachers & 6 & 7.5 \\
Housewife & 44 & 55 \\
Private employment & 7 & 8.8 \\
Merchant & 4 & 5 \\
\hline
\end{tabular}

\begin{tabular}{lcc}
\hline Nurse & 1 & 1.3 \\
Farmer & 3 & 3.8 \\
Civil Employment & 1 & 1.3 \\
Private & 9 & 11.3 \\
Vegetable vendors & 1 & 1.3 \\
Entrepreneur & 3 & 3.8 \\
Total & 80 & 100 \\
\hline
\end{tabular}

Table 3 provides information about the respondent's work status in this study. Forty-four respondents were housewives, while respondents who work as health workers like midwives or nurses were two respondent.

Most respondents are housewives $(55 \%)$, so they had time to attend prenatal classes. It indicated by the activeness of mothers attending prenatal classes by $78 \%$. Widianingrum (2014) stated that mothers who did not work or become housewives would be more focused on caring for their baby every day. According to Masini (2015), many people think that the husband was the one who has to work, and the wife should be at home taking care of their children. (9) Also, according to Anasari (2013) stated that working mothers have little time to attend prenatal classes. ${ }^{[10]}$

Table 4 Frequency Distribution of The Participation of Pregnant Women

\begin{tabular}{lll}
\hline Participation & f & \% \\
\hline 1-2 times & 21 & 26.3 \\
3-4 times & 59 & 73.7 \\
Total & 80 & 100 \\
\hline
\end{tabular}

The participation of pregnant women in table 4 classified into 1-2 times group and 3-4 times group. Respondents who attended prenatal classes 3-4 times were 59 respondents. While respondents who attended prenatal classes about 1-2 times were 21 respondents, participants are said actively participate if the frequency of participating in the prenatal class 
were three times during their pregnancy. From the results of this study, most respondents actively participated in the prenatal class.

Provision of information about postnatal care through prenatal classes is needed, this was also stated by Yustiawan and Nandini (2018) precise information about the needs of postnatal mothers must be provided by competent sources such as health workers because besides getting information, health consultations can also be done. ${ }^{[11]}$

Table 5 Frequency distribution of maternal behavior during postnatal

\begin{tabular}{lcc}
\hline Behavior & f & \% \\
\hline Poor & 9 & 11.3 \\
Excellent & 71 & 88.8 \\
Total & 80 & 100 \\
\hline
\end{tabular}

The behavior of postnatal mothers in the excellent category was 71 respondents, while respondents with poor behavior were nine respondents.

The results obtained from respondents who had poor behavior in postnatal care was the existence of culture in a society that was still accustomed to any restrictions in food. Postnatal mothers need adequate protein intake to accelerate the healing of perineal wounds, but due to differences in perception/culture that considers consuming fish, meat, and eggs could cause itching and prolong the healing process.

Also, some respondents limited the intake of fluids in the form of drinking water because they think that drinking water can slow down the wound to become dry. Rahayu et al. (2017) explained that culture is very influential in postnatal care ${ }^{[12]}$.

b. Bivariate Analysis

Bivariate analysis performed to analyze the relationship between two variables. This study used crosstabulation and chi-square analysis. Cross tabulations between participation and behavior are presented in Table 6 below.

Table 6 Cross Tabulation Between Prenatal Class Participation And Behavior

\begin{tabular}{lcccc}
\hline & \multicolumn{2}{c}{$\begin{array}{c}\text { Prenatal } \\
\text { Class } \\
\text { Participation }\end{array}$} & Total & $\begin{array}{c}\text { p- } \\
\text { value }\end{array}$ \\
\cline { 2 - 4 } & $\begin{array}{c}\mathbf{1 - 2} \\
\text { times }\end{array}$ & $\begin{array}{c}\mathbf{3 - 4} \\
\text { times }\end{array}$ & & \\
\hline Poor & 7 & 2 & 9 & 0.001 \\
Excellent & 14 & 57 & 71 & \\
\hline
\end{tabular}

Based on the cross-tabulation table above, it shows that 57 respondents who have good behaviors fall into the category of participated about 3-4 times. While of the nine respondents who have poor behavior, 7 of them attend the prenatal class about 1-2 times.

Based on the results of the analysis above, it shows that there were $25 \%$ of cells that have a value of less than five so that the relationship analysis was conducted using the Fisher Analysis approach. Fisher analysis results have a significance value of 0.001 . This value is smaller than $0.05(5 \%)$, so it can be concluded that there is a significant relationship between prenatal class participation and maternal behavior during postnatal.

The results show that there is a significant relationship between prenatal class participation with maternal behavior during postnatal. As explained in the Ministry of Health of the Republic of Indonesia (2011), a prenatal class held in order to increase maternal knowledge about one of them being postnatal care. Most respondents in this study had taken the class of pregnant women during their pregnancy. It shows that mothers who actively attend prenatal classes were attending 3-4x. When attending prenatal classes, they get 
information about procedures for postnatal care, which includes the understanding of the puerperium, type of postnatal care, benefits, and procedures for postnatal care.

Howell (2010), in his study, stated that the lack of preparation for the postnatal experience, including failure to discuss common physical and emotional symptoms, was associated with reduced patient satisfaction. Lack of maternal experience in the puerperium, one of which was influenced by knowledge about puerperium ${ }^{[13]}$. As stated by Joharmi and Netti (2017) that knowledge was one of the supporting factors in the success of behavior in postnatal care.

A person's behavior formed from the experiences and external factors ${ }^{[14]}$. Postnatal behavior includes nutrition care, personal hygiene, activity or exercise, rest, breast care, family planning, health examination, and complications detection ${ }^{[15]}$. According to interviews, postnatal care was supported by health workers and cadres. Postnatal visits were always done routinely to monitor the success of postnatal care. Postnatal visits were not only routinely carried out at home but also to Community Health Center or Midwife Private Practices. Besides going through prenatal classes, the socialization carried out by health workers was usually done at the posyandu.

\section{Conclusion}

Prenatal classes have a significant relationship in improving maternal behavior regarding postnatal care. Therefore, it is necessary to increase the participation of pregnant women in the prenatal class, as providing information earlier and used appropriate methods will form good attitudes and knowledge, where the result would be a positive maternal behavior during postnatal.

\section{Acknowledgment}

This study was funded by the Ministry of Research and Technology in the 2019 research grant program.

\section{References}

[1] Kemenkes RI. Profil Kesehatan Indonesia. Jakarta. 2016. www.depkes.go.id/.../profilkesehatan-indonesia/Profil-

Kesehatan Indonesia-2016.pdf (Diakses tanggal 28 September 2018)

[2] Kabupaten Kediri. Profil Kesehatan Kabupaten Kediri. 2016. www.dinkes.kedirikab.go.id/?hal= dprofilkesehatan\&id=51 ( Diakses tanggal 28 September 2018)

[3] Kemenkes RI . 2011. Pedoman Pelaksanaan Kelas Ibu Hamil. Jakarta

[4] Notoatmojo S. 2014. Ilmu perilaku kesehatan. Rineka Cipta. Jakarta

[5] Widiyaningrum RS. Pengaruh Kelas Ibu Hamil dengan Masa Nifas di Kabupaten Sragen. Tesis. Universitas Muhammadiyah Surakarta. 2014.

[6] Joharmi dan Etalia, N. Faktorfaktor yang mempengaruhi ibu melakukan perawatan masa nifas di desa Sei Rakyat Kecamatan Medang Beras Kabupaten Batu bara. Jurnal Imiah Maksitex. 2017. 2(4): 78-89

[7] Pertiwi R, Suyatno, Dharminto. Hubungan Keikutsertaan Kelas Ibu Hamil dan Dukungan Sosial Keluarga. 2017.

[8] Hardjito K, Pratamaningtyas S, Novitasari D. Hubungan

Keikutsertaan Kelas Ibu Hamil Terhadap Kesiapan Perawatan Bayi Pada Fase Taking in di wilayah Kerja Puskesmas Wates Kabupaten Kediri. Jurnal Global Health Science. 2018. 3(1): 61-67

[9] Masini. Pengaruh Gravida, Pekerjaan, Dukungan Suami, Dukungan Bidan/ Tenaga Kesehatan, Terhadap Partisipasi Ibu Dalam Kelas Ibu Hamil di 
Kabupaten Magelang. Jurnal

Kebidanan. 2015. 4(8):37-44

[10] Anasari T. Analisis faktor-faktor yang berhubungan dengan keikutsertaan kelas ibu hamil dalam melakukan senam hamil pada kelas ibu hamil. Akademi Kebidanan YLPP Purwokerto. 2013.

[11] Yustiawan T, Nandini N. 2018. Literasi informasi kesehatan nifas ibu hamil berstatus sosial menengah ke bawah. Jurnal Administrasi Kesehatan Indonesia. 2018. 6(2): 122-128.

[12] Sri Rahayu I, Mudatsir, Hasballah K. Cultural Factors In Treatment In The Postpartum Mother. Jurnal Ilmu Keperawatan. 2017. 5(1): 37 49.

[13] Howell, E.A. lack patient preparation for the postpartum period and patients' satisfaction with their obstetric clinicians. Obstet Gynecol, 115 (2 pt 1): 2849. 2010.

[14] Eldawati, Sagita. Hubungan pengetahuan dan sikap ibu nifas dengan praktik perawatan masa nifas di kecamatan Gunungpati Kota Semarang. Jurnal Kesehatan Masyarakat Universitas Diponegoro.2016. 2(3): 228-237.

[15] Anisatul K, M. Zen Rahfiludin, Martha Irena K. 2016. Hubungan keikutsertaan kelas ibu hamil terhadap perilaku ibu dalam perawatan nifas. Jurnal Kesehatan Masyarakat Universitas Diponegoro. 2016. 4(3): 147-157 